\title{
Emission of sunscreen salicylic esters from desert vegetation and their contribution to aerosol formation
}

\author{
S. N. Matsunaga ${ }^{1,2}$, A. B. Guenther ${ }^{2}$, M. J. Potosnak ${ }^{3}$, and E. C. Apel ${ }^{2}$ \\ ${ }^{1}$ Advanced Study Program, National Center for Atmospheric Research, 3450 Mitchell Lane, Boulder CO 80301, USA \\ ${ }^{2}$ Atmospheric Chemistry Division, National Center for Atmospheric Research, 3450 Mitchell Lane, Boulder CO 80301, USA \\ ${ }^{3}$ Desert Research Institute, 2215 Raggio Parkway, Reno, NV 89512, USA
}

Received: 21 May 2008 - Published in Atmos. Chem. Phys. Discuss.: 16 July 2008

Revised: 7 October 2008 - Accepted: 13 October 2008 - Published: 11 December 2008

\begin{abstract}
Biogenic volatile organic compounds (BVOC) produced by plants are known to have an important role in atmospheric chemistry. However, our knowledge of the range of BVOCs produced by different plant processes is still expanding, and there remain poorly understood categories of BVOCs. In this study, emissions of a novel class of BVOC emissions were investigated in a desert region. Our study considered 8 species of common desert plants: blackbrush (Coleogyne ramosissima), desert willow (Chilopsis linearis), mesquite (Prosopis glandulosa), mondel pine (Pinus eldarica), pinyon pine (Pinus monophylla), cottonwood (Populus deltoides), saguaro cactus (Carnegiea gigantea) and yucca (Yucca baccata). The measurements focused on BVOCs with relatively high molecular weight $\left(>\mathrm{C}_{15}\right)$ and/or an oxygenated functional group. Significantly high emission rates of two salicylic esters were found for blackbrush, desert willow and mesquite with emission rates of 3.1, 1.0 and $4.8 \mu \mathrm{gC} \mathrm{dwg}{ }^{-1} \mathrm{~h}^{-1}$, respectively (dwg; dry weight of the leaves in gram). The salicylic esters were identified as 2-ethylhexenyl salicylate (2-EHS) and 3,3,5-trimethylcyclohexenyl salicylate (homosalate) and are known as effective ultraviolet (UV) absorbers. We propose that the plants derive a protective benefit against UV radiation from the salicylic esters and that the emission process is driven by the physical evaporation of the salicylic esters due to the high ambient temperatures. In addition, the salicylic esters are predicted to be an effective precursor of secondary organic aerosol (SOA) because they probably produce oxidation products that can condense onto the aerosol phase. We estimated the contribution of the sunscreen esters themselves and their oxidation products on the SOA formation for the Las Vegas area using a BVOC emission model. The contribution was estimated to reach $50 \%$ of the biogenic terpenoid
\end{abstract}

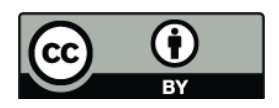

Correspondence to: Sou Matsunaga (sou@tmu.ac.jp) emission in the landscapes dominated by desert willow and mesquite and 13\% in the Las Vegas area. The contributions to biogenic SOA are likely to be higher due to the potentially high SOA yields of these compounds.

\section{Introduction}

Aerosol particles have a significant role for regional air quality and global climate change. In addition to their direct release into the atmosphere (primary aerosol), aerosol can also be formed by condensation of oxidation products of the atmospheric volatile organic compounds (VOCs) and is then classified as secondary organic aerosol (SOA). Because SOA is generated from molecules in the gas phase, it tends to be finer and has a longer residence time in the atmosphere than primary aerosols (Fuzzi et al., 2006). Terrestrial vegetation emits a significant amount of reactive VOCs into the atmosphere, known as biogenic VOCs (BVOCs). The most common BVOCs include isoprene (2-methyl-1,3-butadiene) and monoterpenes ( $\mathrm{C}_{10}$ hydrocarbons). The global emission of BVOCs is almost an order of magnitude larger than that of VOCs from human activities (Guenther et al., 2006). In addition, BVOCs are generally very reactive and produce oxygenated and polar compounds via the degradation process (Atkinson and Arey, 1998). A portion of these products forms SOA in the atmosphere. For example, oxidation of monoterpenes led to SOA formation in a forest (Kavouras et al., 1999), and the oxidation products of isoprene also contribute to the aerosol fraction (Matsunaga et al., 2003; Claeys et al., 2004; Matsunaga et al., 2005; van Donkelaar et al., 2007). Because of both SOA formation and gas phase photochemistry, BVOC emissions impact both regional air quality and the global climate.

However, it is likely that we know only a part of the total range of BVOC species being released into the atmosphere because of limitations of analytical techniques and the lack

Published by Copernicus Publications on behalf of the European Geosciences Union. 
of investigations in some landscapes. In particular, scientists have inferred that more BVOCs exist than are routinely measured (Goldstein et al., 2004; Di Carlo et al., 2004) and compounds with a relatively high molecular weight (around $\mathrm{C}_{15}$ ) have been targeted for study. One class of BVOCs that have received more recent attention are the sesquiterpenes (SQT), which are terpenoids with a very high reactivity, in most cases, in the atmosphere (Helmig et al., 2006; Duhl et al., 2007). Because SQTs have 15 carbon atoms, the degradation process can result in multiple generations of products. Therefore, the entire atmospheric degradation time of SQTs can be longer than that of smaller VOC even though the lifetime of the original VOC is shorter. These products will be oxygenated, which lowers their vapor pressure and favors SOA formation.

There are potentially many other BVOCs with high molecular weights that also could be involved in SOA production; the esters 2-ethylhexenyl salicylate (2-EHS) and 3,3,5trimethylcyclohexenyl salicylate (homosalate) are two candidates. These compounds are used as an active ingredient in commercial sunscreen products due to their UV absorption. In a similar manner to how plants employ flavonoid compounds to protect their DNA from UV radiation damage (Stapleton and Walbot, 1994), desert plants may employ these sunscreen esters as a protective mechanism. Because 2EHS and homosalate are $\mathrm{C}_{15}$ and $\mathrm{C}_{16}$ salicylic esters, respectively, they will evaporate only at high ambient temperatures but may be released into the atmosphere in hot environments. Analogous to SQTs, these sunscreen esters are expected to degrade and form semi-volatile products. Because of oxygenation during these degradation steps, the entire SOA yield can be more than unity. These sunscreen esters represent a previously unknown source of SOA, and here we report for the first time the emission rates of the sunscreen esters from desert plants and a model estimate of the potential contribution of these esters to SOA production.

\section{Experiment}

\subsection{Sample collection and treatment}

Plant enclosure sampling was performed between 1 July and 6 July 2006 from typical urban and wild land desert shrubs and trees at four sites located in the Las Vegas, NV, USA area: a desert shrubland, a golf course, the campus of the Desert Research Institute and at a city public park. The SQT samples were collected from 8 species of typical plants for this area. Leaves or small branches were enclosed in a 1liter glass cuvette with a temperature control (Fig. 1). The SQT samples were collected also with a large Teflon enclosure bag without temperature control for some plants. Therefore, there were two simultaneous samples for some plants. The internal temperature of the cuvette was set to approximately ambient air temperature $\left(25-35^{\circ} \mathrm{C}\right)$. Air, purified with

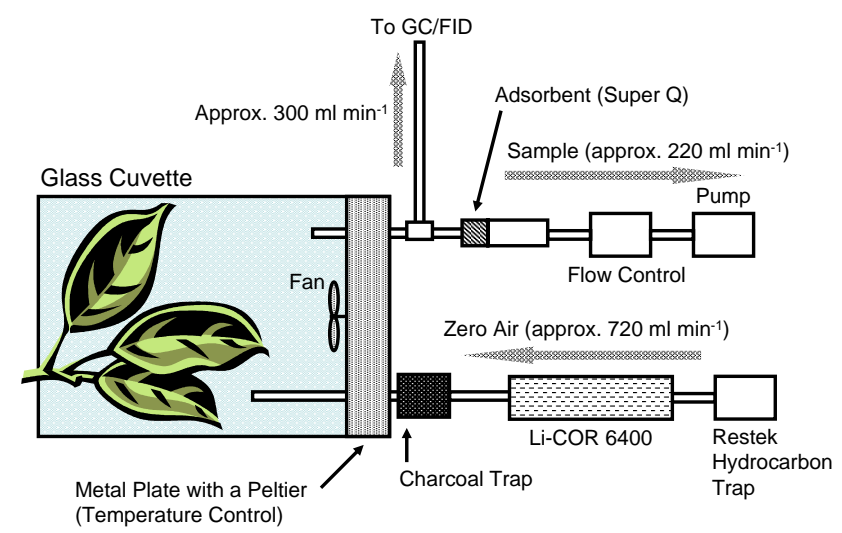

Fig. 1. A schematic of the plant enclosure.

a coconut charcoal trap (Orbo tube, Supelco, Bellefonte, PA, USA), flowed continuously through the glass cuvette at a rate of $720 \mathrm{ml} \mathrm{min}^{-1}$. While $\mathrm{CO}_{2}$ concentration may be changed by the charcoal trap, the resulting $\mathrm{CO}_{2}$ concentrations remained close to ambient levels. $\mathrm{CO}_{2}$ and water vapor concentrations of the air entering the cuvette was analyzed with a Li-COR 6400 (Li-COR Biosciences, Lincoln NE, USA). The Li-COR 6400 also had a second trap (Restek Hydrocarbon Trap, Restek, Bellefonte PA, USA) on its air inlet to remove ambient hydrocarbons and ozone. Air for SQT analysis was withdrawn from the enclosure at a rate of $220 \mathrm{ml} \mathrm{min}^{-1}$, and sampling times ranged from 1.5 to $4 \mathrm{~h}$. In addition, some samples were collected from a Teflon bag (approximately 10 liter) without temperature control.

VOC contained the sample air was collected onto $30 \mathrm{mg}$ of Super Q adsorbent (Alltech, Columbia MD, USA) in a $6.3 \mathrm{~mm}$ diameter glass tube (Volatile Collection Trap, Analytical Research Systems, Inc., Gainesville FL, USA). Collected compounds were extracted from the adsorbent immediately after sampling with approximately $2 \mathrm{ml}$ of dichloromethane. After extraction from the collection trap, the samples were placed into $2 \mathrm{ml}$ glass vials, sealed with a plastic cap with PTFE liner and stored in a freezer (approximately $-15^{\circ} \mathrm{C}$ ) prior to being shipped back to the NCAR (Boulder, CO, USA) laboratory for analysis. Although they were covered with coolants, the samples may have been exposed to above-freezing temperatures $\left(0-10^{\circ} \mathrm{C}\right)$ during shipping. The extracts were concentrated in the laboratory by evaporating the solvent with a gentle argon flow to less than approximately $2-3 \mu \mathrm{l}$, and then $30 \mu \mathrm{l}$ of hexane was added to the vial to adjust the volume. About $60 \%$ of the compound is lost during the concentration process, however, this loss factor is relatively stable (varies $5-10 \%$, approximately). The loss factor was considered when calculating the emission rate. The concentrated solutions were stored in the freezer until analysis. 

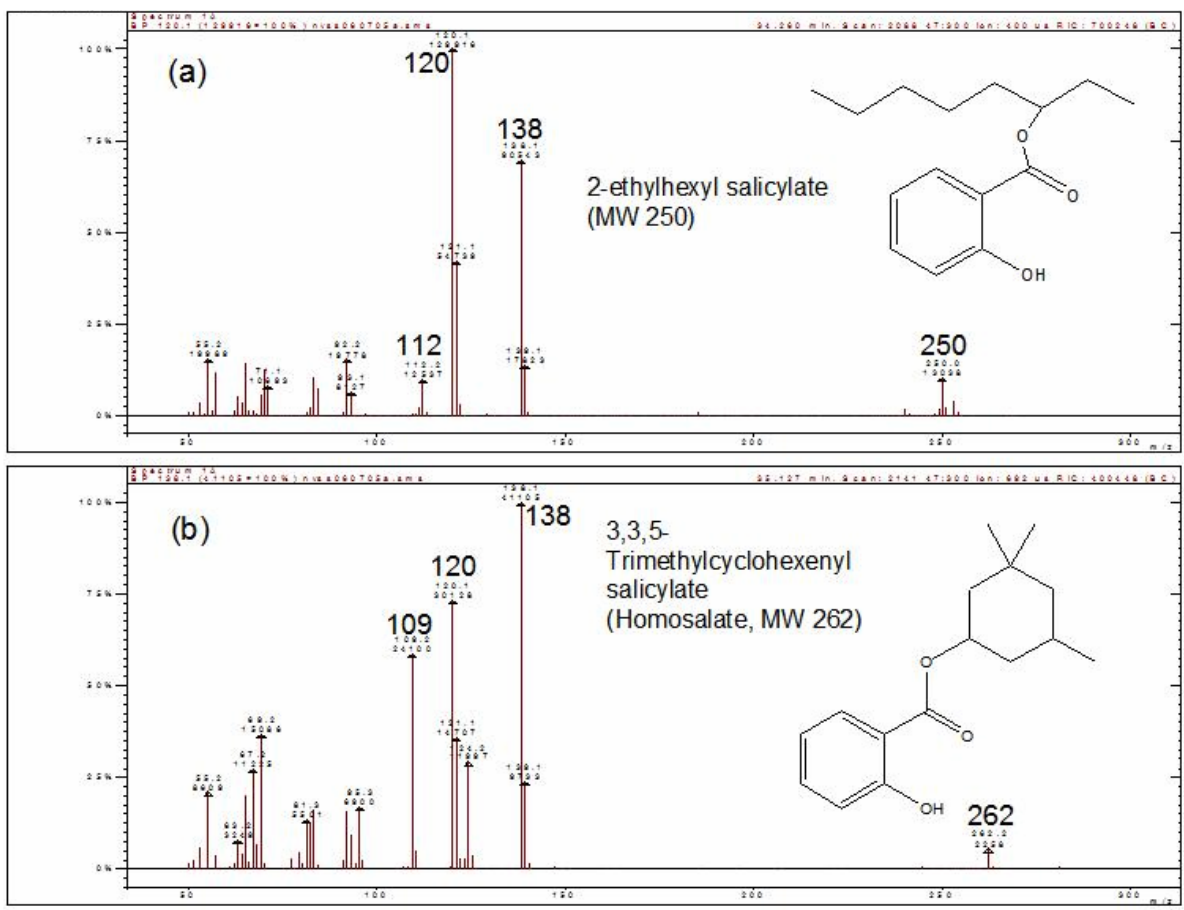

Fig. 2. Chemical structure and ion trap mass spectrums of (a) 2-ethylhexyl salicylate and (b) 3,3,5-trimethylcyclohexenyl salicylate.

\subsection{Analysis}

A gas chromatograph (GC, HP5890GC, Agilent Technologies, USA) with a flame ionization detector (FID) was used for separation and quantification of the compounds. The esters were identified using a gas chromatograph mass spectrometer (GC/MS, Saturn 2000, Varian, USA), and their GC retention times were compared with those of the authentic standards (see Fig. 2 for mass spectra). The mass spectra and GC retention time of the GC peaks of the standard and sample showed a reasonable agreement. The GC is equipped with a cold on-column injector and fused silica capillary column (HP-5, $0.32 \mathrm{~mm}$ i.d., $0.5 \mu \mathrm{m}$ film thickness, $60 \mathrm{~m}$ ) and uses helium as carrier gas. A $2 \mu 1$ aliquot of the concentrated solution of the sample was injected into the GC. Compounds were identified by comparison of retention time with authentic standards and were quantified by comparison of peak area with a standard solution of the authentic standards which were gravimetrically quantified. Calibrations using a standard solution were performed every day and used to determine the amount of the compounds in samples injected within the same day. Control (blank) samples were also collected directly from zero air flow. Obtained peak areas from the sample analysis were corrected based on loss factor which characterizes the fraction of the esters that remains in the final vial after the concentration process. The loss factor was 0.45 for both 2-EHS and homosalate and was obtained by a comparison of peak area of compounds in Ar concentrated solution and in a diluted solution based on gravimetrically determined concentration without any concentration process. The uncertainty associated with the loss factor is about $12 \%$ based on the standard deviation of repeated measurements because almost all of the uncertainty is derived from the concentration process. The emission rates of the esters discussed in this report are adjusted using the loss factor.

\subsection{Emission model}

Salicylic ester emission factors determined from this study were incorporated into the MEGAN biogenic emission model (Model of Emissions of Gases and Aerosols from Nature, Guenther et al., 2006). MEGAN includes methods for characterizing and processing land cover type and density, improved simulation of canopy environment including leaf energy balance calculations, light penetration through varying canopy types, and detailed chemical speciation. MEGAN is a global model but has a $1 \mathrm{~km}$ spatial resolution and so can be used for regional modeling. The landcover inputs used to drive MEGAN are based on remote sensing observations that were calibrated with ground measurements described by Papiez et al. (2008). 
Table 1. Observed emission rate and emission factor of the salicylic esters from desert plants.

\begin{tabular}{|c|c|c|c|c|c|c|c|c|c|c|c|c|}
\hline \multirow{2}{*}{$\begin{array}{l}\text { Common Name } \\
\text { Species } \\
\text { Sample Collection }\end{array}$} & \multicolumn{2}{|c|}{$\begin{array}{c}\text { Mondel Pine } \\
\text { Pinus } \\
\text { eldarica }\end{array}$} & \multirow{2}{*}{$\begin{array}{c}\text { Black Brush } \\
\text { Coleogyne } \\
\text { ramosissima }\end{array}$} & \multirow{2}{*}{$\begin{array}{c}\text { Pinyon Pine } \\
\text { Pinus } \\
\text { monophylla }\end{array}$} & \multirow{2}{*}{$\begin{array}{c}\begin{array}{c}\text { Yucca } \\
\text { Yucca } \\
\text { baccata }\end{array} \\
\begin{array}{c}\text { Cuvette } \\
4 \text { Jul }\end{array}\end{array}$} & \multicolumn{2}{|c|}{$\begin{array}{l}\text { Mesquite } \\
\text { Prosopis } \\
\text { glandulosa }\end{array}$} & \multicolumn{2}{|c|}{$\begin{array}{l}\text { Populus } \\
\text { Populus } \\
\text { deltoides }\end{array}$} & \multicolumn{2}{|c|}{$\begin{array}{c}\text { Desert Willow } \\
\text { Chilopsis } \\
\text { linearis }\end{array}$} & \multirow{2}{*}{$\begin{array}{c}\text { Saguaro Cactus } \\
\text { Carnegiea } \\
\text { gigantea }\end{array}$} \\
\hline & $\begin{array}{c}\text { Cuvette }^{1} \\
3 \mathrm{Jul}\end{array}$ & $\mathrm{Bag}^{2}$ & & & & $\begin{array}{c}\text { Cuvette } \\
5 \mathrm{Jul}\end{array}$ & Bag & $\begin{array}{c}\text { Cuvette } \\
5 \mathrm{Jul}\end{array}$ & Bag & $\begin{array}{c}\text { Cuvette } \\
6 \mathrm{Jul}\end{array}$ & Bag & \\
\hline Mean time (local) & $14: 35$ & $15: 29$ & $12: 13$ & $14: 34$ & $16: 14$ & $11: 50$ & $12: 17$ & $15: 19$ & $15: 25$ & $11: 40$ & $13: 24$ & $15: 56$ \\
\hline Leaf Temp C & 35.1 & $*$ & 34.2 & 29.4 & 31.2 & 36.8 & $*$ & 24.9 & * & 35.2 & $*$ & 35.4 \\
\hline Relative humidity inside $\%$ & 49.1 & & 54.8 & 73.6 & 22.5 & 51.6 & & 61.2 & & 50.2 & & 25.1 \\
\hline Relative humidity outside $\%$ & 21.6 & & 26.2 & 33.3 & 28.4 & 38.3 & & 31.6 & & 18.2 & & 24.7 \\
\hline Light intensity $\mu \mathrm{mol} \mathrm{m}{ }^{-2} \mathrm{~s}^{-1}$ & 260 & & 459 & 400 & 708 & 1843 & & 39 & & 226 & & 409 \\
\hline $\begin{array}{l}\text { Emission Rate, } E \\
\left(\mu \mathrm{gCdwg}^{-1} \mathrm{~h}^{-1}\right)\end{array}$ & & & & & & & & & & & & $\left(\mu \mathrm{gCcm}^{-2} \mathrm{~h}^{-1}\right)$ \\
\hline 2-EHS & 0.034 & 0.005 & 2.5 & 0.058 & 0.024 & 0.44 & 0.91 & 0.016 & 0.24 & 0.97 & 4.00 & $1.1 \mathrm{E}-03$ \\
\hline Homosalate & 0.122 & 0.040 & 0.60 & 0.062 & 0.033 & 0.59 & 3.50 & 0.038 & 1.00 & 3.8 & 10.7 & $3.7 \mathrm{E}-03$ \\
\hline Total & 0.156 & 0.045 & 3.1 & 0.120 & 0.057 & 1.03 & 4.41 & 0.054 & 1.24 & 4.8 & 14.7 & $4.8 \mathrm{E}-03$ \\
\hline
\end{tabular}

1: The glass cuvette with a temperature control.

2: A Teflon bag without temperature control.

$*$ : No temperature record, but leaf temperature in the bag tends to be higher than that of the cuvette.

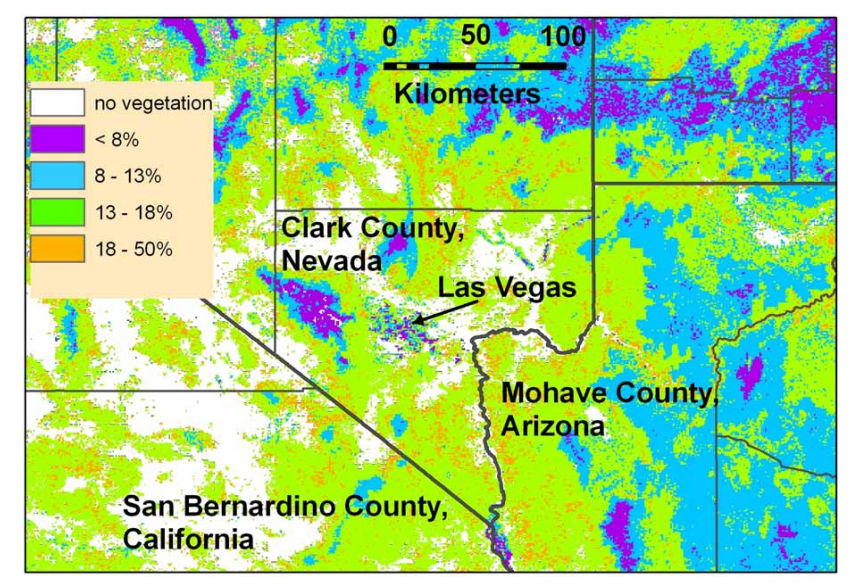

Fig. 3. Contribution of 2-ethylhexenyl salicylate and 3,3,5methylcyclohexenyl salicylate to total $\mathrm{C} 10$ to $\mathrm{C} 16$ biogenic VOC emission.

\section{Results and discussion}

\subsection{Emission rates of the sunscreen esters}

The emission rates from foliage exposed to temperatures around $32^{\circ} \mathrm{C}$ for 2 -EHS and homosalate varied from 0.1 to $1 \mu \mathrm{gC} \mathrm{dwg}^{-1} \mathrm{~h}^{-1}$ and $3.8 \mu \mathrm{gC} \mathrm{dwg}^{-1} \mathrm{~h}^{-1}$, respectively (see Table 1). The emission of the salicylic esters is probably temperature dependent, with higher emissions at higher temperatures, because the emission process is most likely evaporation from the plant surface, but there was no signficnat correlation with temperature over the small temperature range observed in this study. The emission rates varied by orders of magnitude which could indicate variability between different plant species. Desert willow (Chilopsis linearis), blackbrush (Coleogyne ramosissima) and mesquite (Prosopis glandulosa) had much higher emission rates compared to the other species.

3.2 Potential contribution of the sunscreen salicylate to total biogenic VOC emissions and potential SOA formation

Isoprene, monoterpene and sesquiterpene emissions for this region have been calculated by Papiez et al. (2008) and used to investigate the impact of these emissions on air quality in this region of rapid urban expansion. This study concludes that the biogenic terpene emission in this region have a significant impact on regional air quality. Here we make a first attempt to determine the contribution of salicylic esters in comparison to these terpene emissions. Since the temperature dependence of the salicylic ester emissions has not been characterized, we have compared emissions for conditions representative of the emission measurements reported for this study. Figure 3 illustrates sunscreen compound contributions to the total monoterpene plus sesquiterpene emissions for this region estimated for full sunlight and moderately hot $\left(32^{\circ} \mathrm{C}\right)$ conditions. The monoterpene and sesquiterpene emissions were estimated using the procedures described by Papiez et al. (2008). The 2-EHS and homosalate emission rate measurements reported in Table 1 were extrapolated to the regional scale using the MEGAN model landcover data. The salicylic esters often contributed at least $13 \%$ of the estimated total from most landscapes and were responsible for up to half of total emissions in landscapes dominated by the high emitting desert willow and mesquite. Additional surveys are needed to determine if there are additional high emitting species and thus high emission landscapes. Since the average 
SOA yields of sesquiterpenes are probably similar and that of monoterpenes are likely to be considerably lower than that of salicylic esters (Sakulyanontvittaya et al., 2008), the contribution of salicylic esters to total SOA is likely to be higher than the contribution of total biogenic VOC emissions.

\section{Conclusions}

Two salicylic esters, which have the capacity to absorb UV radiation, have been identified as being significant emissions from plants living in a desert environment. Assuming an aerosol yield of 1 for these sunscreen esters, they are found to have a substantial contribution to biogenic secondary organic aerosol (SOA) formation in the Las Vegas area. This study is the first report that salicylic esters are being emitted into the atmosphere from desert plants. These emissions could be a significant factor for SOA formation, at least in desert regions, and additional studies are needed to quantify this potentially important contribution.

Acknowledgements. This study was supported by the Advanced Study Program in National Center for Atmospheric Research which is sponsored by the National Science Foundation, the National Risk Management Research Laboratory of the US Environmental Protection Agency, and the Clark County Division of Air Quality and Environmental Management.

Edited by: R. Ebinghaus

\section{References}

Atkinson, R. and Arey, J.: Atmospheric Chemistry of Biogenic Organic Compounds, Accounts Chem. Res., 31(9), 574-583, 1998.

Claeys, M., Graham, B., Vas, G., et al.: Formation of secondary organic aerosols through photooxidation of isoprene, Science, 303, 1171-1176, 2004.

Di Carlo, P., Brune, W. H., Martinez, M., et al.: Missing OH Reactivity in a Forest: Evidence for Unknown Reactive Biogenic VOCs, Science, 304, 722-725, 2004.

van Donkelaar, A., Martin, R. V., Park, R. J., et al.: Model evidence for a significant source of secondary organic aerosol from isoprene, Atmos. Environ., 41, 1267-1274, 2007.

Fuzzi, S., Andreae, M. O., Huebert, B. J., Kulmala, M., Bond, T. C., Boy, M., Doherty, S. J., Guenther, A., Kanakidou, M., Kawamura, K., Kerminen, V.-M., Lohmann, U., Russell, L. M., and Pöschl, U.: Critical assessment of the current state of scientific knowledge, terminology, and research needs concerning the role of organic aerosols in the atmosphere, climate, and global change, Atmos. Chem. Phys., 6, 2017-2038, 2006,

http://www.atmos-chem-phys.net/6/2017/2006/.
Goldstein, A. H., McKay, M., Kurpius, M. R., et al.: Forest Thinning Experiment Confirms Ozone Deposition to Forest Canopy is Dominated by Reaction with Biogenic VOCs, Geophys. Res. Let., 31, L22106, doi:10.1029/2004GL021259, 2004.

Guenther A. B., Zimmerman, P. R., Harley, P. C., et al.: Isoprene and monoterpene emission rate variability: Model evaluations and sensitivity analyses, J. Geophys. Res., 98, 12 609-12 617, 1993.

Guenther, A., Karl, T., Harley, P., Wiedinmyer, C., Palmer, P. I., and Geron, C.: Estimates of global terrestrial isoprene emissions using MEGAN (Model of Emissions of Gases and Aerosols from Nature), Atmos. Chem. Phys., 6, 3181-3210, 2006, http://www.atmos-chem-phys.net/6/3181/2006/.

Helmig, D., Ortega, J., Guenther, A., et al.: Sesquiterpene emissions from loblolly pine and their potential contribution to biogenic aerosol formation in the Southeastern US, Atmos. Environ., 40(22), 4150-4157, 2006.

Kavouras, I. G., Mihalopoulos, N., and Stephanou, E. G.,: Secondary Organic Aerosol Formation vs Primary Organic Aerosol Emission: In Situ Evidence for the Chemical Coupling between Monoterpene Acidic Photooxidation Products and New Particle Formation over Forests, Environ. Sci. Technol., 33, 1028-1037, 1999.

Matsunaga, S., Mochida, M., and Kawamura, K.: Growth of organic aerosols by semi-volatile carbonyls in the forestal atmosphere, Atmos. Environ., 35, 2045-2050, 2003.

Matsunaga, S. N., Wiedinmyer, C., Guenther, A. B., Orlando, J. J., Karl, T., Toohey, D. W., Greenberg, J. P., and Kajii, Y.: Isoprene oxidation products are a significant atmospheric aerosol component, Atmos. Chem. Phys. Discuss., 5, 11 143-11 156, 2005, http://www.atmos-chem-phys-discuss.net/5/11143/2005/.

Matsunaga, S. N., Guenther, A. B., Greenberg, J. P., et al.: Measurement of sesquiterpenes and oxygenated sesquiterpenes from desert shrubs and temperate forest trees using a liquid extraction technique, Geochem. J., in press, 2008.

Papiez, M., Potosnak, M., Goliff, W., Guenther, A., Matsunaga, S., and Stockwell, W.: The Impacts of Reactive Terpene Emissions from Plants on Air Quality in Las Vegas, Nevada, Atmos. Environ, in review, 2008.

Sakulyanontvittaya, T., Duhl, T., Wiedinmyer, C., et al.: Monoterpene and Sesquiterpene Emission Estimates for the United States, Environ. Sci. Technol., 42, doi:10.1021/es702274e, 1623-1629, 2008.

Stapleton, A. E. and Walbot, V.: Flavonoids Can Protect Maize DNA from the Induction of Ultraviolet-Radiation Damage, Plant Physiology, 105, 3, 881-889, 1994. 